IBIMA Publishing

Communications of the IBIMA

http://www.ibimapublishing.com/journals/CIBIMA/cibima.html

Vol. 2016(2016), Article ID 187526, 17 pages

DOI: $10.5171 / 2016.187526$

Research Article

\title{
The Effects of Governance Mechanisms On the Financial Information Quality
}

\author{
Ramzi Belhadj ${ }^{1}$, Amina Omrane $^{2}$ and Boutheina Regaieg ${ }^{3}$ \\ ${ }^{1,3}$ FSEGT, Tunis-El Manar, Tunisia \\ ${ }^{2}$ FSEGS, Sfax and IHEC-Carthage, Tunisia
}

Correspondence should be addressed to: Amina Omrane; amina.omrane@yahoo.fr

Received date: 8 September 2015; Accepted date: 2 October 2015; Published date: 8 April 2016

Copyright (C) 2016. Ramzi Belhadj, Amina Omrane and Boutheina Regaieg. Distributed under Creative Commons CC-BY 4.0

\begin{abstract}
This study investigates the impact of some mechanisms corporate governance, in this case, the Board of Directors and its characteristics, the auditing quality and ownership structure, on the earnings management. For this purpose, we used a sample of 16 Tunisian listed companies. The earning management was operationalized by the level of the discretionary accruals. Besides, another variable relative to the company's size was used. When looking at the achieved results, we highlight that that earning management is positively related to the ownership structure and the size of the company. However, no association was found between the Board of Directors, the quality of audit on the one hand, and the level of the discretionary accruals on the other hand.
\end{abstract}

Keywords: earnings management, discretionary accruals, board of directors, ownership structure, company size.

\section{Introduction}

Accounting and financial information is important for the users of financial statements. It is therefore an essential component of the economy. For this reason, any manipulation or fraud that affects the basic accounting information could affect the economy as a whole. This raises the question of whether the financial information provided by companies is reliable or not. Moreover, the financial scandals that marred some companies in the world, such as the "Enron" American oil company, the "WorldCom", "Xerox" and the Italian "Parmalat" dairy group, suggest the caution taken against the production and the use of financial information. Actually, the accounting regulatory agencies, the authorities acting on the financial markets and the different users of financial information questioned both the transparency and credibility of financial information. Therefore, controlling and preparing financial information have become more than essential.

In this context, it is the challenge of corporate governance which seems to have an important role. This is especially the case with mechanisms that support the company's management, and all the tools providing a system to limit the discretionary space of the company's leader (Charreaux, 1997). In addition, the use of corporate governance is justified by the fact that it is the subject of several debates over the last ten years 
simultaneously with the publication of the Cadbury, Viénot reports and many others.

According to the OECD (Organization for Economic Cooperation and Development), corporate governance could fully contribute to the development of the relationships between several stakeholders, namely the shareholders, capital owners, investors and employees. For this purpose, we tend to see that investors and users of financial statements, in a broader sense, have interest in controlling the lead against the manager's opportunistic behavior that resides in earnings management.

It should be noted that at this stage, the corporate governance mechanisms are broken down into both external mechanisms (such as the market for goods and services, the executive job market and the stock market) and internal mechanisms (such as the board of directors, ownership structure and the compensation or financial inducement policy).

Moreover, since the book income is a variable on which the leaders can act, the outcome management as a whole could be taken into account (Shipper, 1989). This is a part of the research conducted in the context of the accounting positive theory and sheds light on the analysis of the accounting choices within the company.

In this context, Watts and Zimmerman (1978) identified three earnings management-based objectives, namely the minimization of the political and financial costs and the maximization of the leaders' wealth. However, if it is obvious that several papers have dealt with the relationship between the governance mechanisms and the level of the earnings management, it should be mentioned that most of these studies have been limited to the effects of some governance mechanisms taken separately. There is also the fact that most of these studies in this domain have been conducted in the developed countries (Stepniewski and Souid (2008) in the French context, Klein (2002), in the American context, Davidson et al. (2005) for Australia, and Loualalen and Khmekhem (2015) in the Canadian context).
Conversely, few studies have been conducted in the developing countries in order to put into perspective a single governance mechanism. Among these studies, we could mention those carried out by Lee (2013) and Alves (2014), who tested the impact of the independence of the Board of Directors on the earnings management in both the Taiwanese and Portuguese contexts. In the end, in the Nigerian context, Salihi and Jibril (2015) have recently underlined the impact of the Board of Directors (through size and the Audit Committee) on the earnings management.

In this perspective, with this contribution, we try to study the impact of governance mechanisms on the earnings management in the Tunisian context. Actually, such an environment is characterized by several specific features of which can be cited: (a) its accounting system gives managers flexibility in the choice of the accounting practices and (b) its financial market consists mainly of small and medium enterprises. In the course of this study, one may wonder therefore about the role of some governance mechanisms in the restriction of the earnings management in Tunisia.

The sample in this study includes 16 companies listed on the Tunis Stock Exchange (TSE) for the period between 2001 and 2010. However, some financial institutions, such as banks, insurance and leasing companies are dropped out from our sample due to their specific accounting rules. Moreover, other companies are excluded due to the data unavailability.

This contribution is structured as follows. The first section is devoted to the literature review and the hypothesis development. Section two presents the sample and the research methodology. The third section rather exposes and interprets the main achieved empirical results before eventually coming to a conclusion.

\section{Literature Review and Hypothesis Development}

Adam and Smith (1776) stated that the company's structure may cause management problems and might lead to 
neglecting the owners' interests. Conflicting interests lead shareholders to define an incentive and control system requiring business executives to behave in accordance with the expected interests at lower costs.

Corporate governance has its roots in the intersection of several theories, including mainly the property rights theory founded by Alchian and Demestez (1972), the Agency theory introduced by Jensen and Mechling (1976), and Fama (1980), the transaction cost theory developed by Williamson (1985) and the entrenchment theory suggested by Shleifer and Vishny (1989).

In their property rights theory, Alchian and Demestez (1972), while enquiring about the modalities for an effective production management in a firm, put forward that collective production (in teams) is more developed than the one generated in a market. They think that this is justified by the existence of a central agent having the role of coordinating and supervising the team work.

For their part, Jensen and Mechling (1976), in what they call the Agency theory, underlined that the firm is nothing but a contract nexus made out between the shareholder and the executive officer. As such, it is the position of the latter at the level of his firm that will enable him to benefit from information and behave in an opportunistic manner at the expense of the shareholders. On that point, the shareholders are encouraged to establish and implement a set of mechanisms of corporate governance in order to limit the discretionary space of the executive officer. Through his famous transaction cost theory, Williamson (1985) assumes that any economic transaction involves costs that can be reduced by means of controlling mechanisms. These mechanisms are not only intentional, to effectively manage the transaction of an institutional nature (like the Governing Council), but also spontaneous and of a contractual nature (in connection with market of goods and services).

On the other hand, in an interpretation of the agency relationship, Shleifer and
Vishny (1989) assume that the controlling mechanism from the leader could be a strategy of entrenchment. Regarding the confrontation between these different strategies, estimating the degree of effectiveness of the controlling systems from the leaders could be achieved. Therefore, in what follows, we will try to present the different internal corporate governance mechanisms developed at the level of the previously mentioned theories and study their impact on the outcome management.

\section{The Board of Directors}

In the context of the agency theory and the transaction costs, Fama (1980), and Williamson (1985), respectively underlined the Board of Directors' role in offering disciplinary and institutional mechanisms used in the company. This Board of Directors has a range of features that can separately play their controlling role, as presented below.

\section{The Board of Directors' Independence}

The agency theory states that the Board's efficiency depends on the proportion of the outside directors it involves. Actually, being independent from the management, the outside directors are more likely to object to the leader's opportunism. For Fama and Jensen (1983), the presence of outside directors, whether they are independent or objective, would lead to the reduction of the agency problems between the executives and the shareholders. Their efficiency in their monitoring job is much appreciated in the context of the labour market, because they most often seek the improvement of their reputation (Fama 1980).

Moreover, the agency theory states that the presence of outside directors and shareholders in firms would drive to having more effective control. Monks and Minow (1995) are also convinced that the administrators can be effective as long as they are shareholders in the firm. From an empirical perspective, most of the studies found a negative correlation between the earnings management and the Board's independence (Peasnell et al, 1998-2000; Klein, 2000) which would imply an 
improvement of the financial information quality.

In the Australian context, Davidson et al (2005) underlined the important role played by the independent Board in the regression of the earnings management practice. On the other hand, Jagi et al (2009) studied the impact of the Board's characteristics on the opportunistic behavior. They could deduce that the Boards in which there is a high proportion of outside directors are appropriately effective in that they restrict the earnings management.

Recently, through a research conducted on a sample of Taiwanese companies, Lee (2013) has, however, underlined the role played by independent directors in improving the result quality. Similarly, Alves (2014) proved that the presence of independent boards of directors representing the Portuguese companies would contribute to improving the quality of the financial information through the prohibition of the level of the discretionary accruals.

Finally, Garven (2015) explored a context completely different from that of the developing countries, the one of the USA. He managed to certify the existence of a negative association between the Board of Directors' independence and the actual earnings management, which involves an improvement of the financial information quality.

From what has just been stated, it can be deduced that the Board of Directors' independence seems to improve the financial information quality, hence, the following hypothesis:

H1: The Board of Directors' independence negatively affects the earnings management.

\section{The Board of Directors' Size}

Pfeffer (1972) assumes that a very largesized Board of Directors enables to increase the potential of expertise and improve the resources of an organization. However, the Board of directors' size could hinder the communication and coordination between the Board's members, as long as it is large. For this purpose, Yermack (1996) pointed out that the smaller the Board of Directors is, the more positively influential it is. In fact, Lipton and Lorch (1992) advocated that the number of directors be between seven and eight members, stating that beyond this number, the Board of Directors becomes inefficient, particularly with respect to the leader's control.

According to Jensen (1993), coordination problems may even arise for the largesized Boards of Directors. In this connection, Hermalin and Weisbach (2003) later added that large-sized Boards of Directors may be less efficient than those which have a restricted number of members insofar as they could generate additional agency costs. Furthermore, several research studies were conducted to test the relationship between the Board of Directors' size and the financial information quality.

Chen et al. (2005), for example, studied the impact of the Board of Directors' size on the earnings management based on a sample of 169 Chinese companies between 1999 and 2003. They reached insignificant results between the Board's size and the existence of fraud. Such results are consistent with the ones reached by Uzum et al (2004), for which there is no correlation between the Board of the Directors' size and the existence of fraud at the level of the financial report.

In the Tunisian context, Omri and Mhiri (2003) conducted an exploration of the relationships that might exist between the characteristics of the Board of Directors and the company's performance. Using a sample of 43 Tunisian companies listed on the Tunisian Stock Exchange, these two authors could show the existence of a statistically significant relationship between the Board's size and the company's performance over the $1995 / 2000$ period. As a result, a Board of Directors of significant size would entail more efficient control.

With a somewhat different problem, the results of the study conducted by Vafeas (2000) in the Anglo-Saxon context, underline the existence of a negative correlation between the Board of Directors' 
size, on the one hand, and the information outcome content, on the other hand.

In Turkey, Aygun and Sayin (2014) in the same line of work of Uwuigbe et al (2014) pointed out the negative impact of the Board of Directors' size on the earnings management measured by the level of the discretionary accruals.

In the light of these different results which too far show a negative relationship between the Board of Directors' size and the earnings management, with which we will be able to align ourselves, as part of this research, by formulating the second hypothesis as follows:

H2: The greater the Board of Directors' size, the lower its impact on the earnings management is.

\section{The Combination or the Separation of Functions and Earnings Management}

The agency theory recommends the function separation since it considers that combing the function of the chief executive officer with that of the Board of Directors' chairman is found to impede the efficiency of the control mechanisms. Actually, the proponents of the agency theory, such as Jensen and Meckling (1976) and Jensen (1993), emphasize that the separation between the management and the decision control functions reduces the agency costs and improves the firms' performance. However, the normal succession theory considers that the dual structure or combination of functions is part of the normal succession used to replace the expelled manager/president.

In this context, many studies were devoted to the impact of the separation of functions on the quality of financial information. Forker (1992), for example, argued that that the separation of functions can increase the quality of control and reduce the probability of information retention of by leaders, which will substantially improve the quality of information disclosure. However, Hanifa and Cooke (2000) could not check the hypothesis according to which the separation of functions positively impacts the extent of the information disclosure. On the other hand, Coulton, et al. (2001) did not find a significant relationship between the function duality and the financial information quality. For their part, Chtourou et al. (2001) got the same result which states that the combination of the two functions has no effect on the reliability of the financial information of the American companies, measured by the level of the earnings management.

Finally, on a sample of 128 French companies belonging to the SBF250 index, Matoussi and Mahfoudh (2010) found that the separation between the functions of the chairman of the Board and those of the chief executive office compels the leader to engage in an "opportunistic" earnings management. This result is in line with the work carried out recently by Kantadu and Samaila (2015).

On the basis of what has just been stated, it can be assumed that the dual structure is highly effective in terms of control, a premise partly founded by the agency theory. Hence, the following hypothesis:

H3: The separation between the chief executive officer's functions and the Chairman's of the Board of Directors is negatively associated with the earnings management.

\section{The Impacts of Ownership Structure}

In addition to the roles played by the Board of Directors in earnings management, there is an internal governance mechanism large enough regarding the ownership structure which was put into perspective by the agency theory. It is the shareholding of which the concentration and composition can significantly impact the power relationships between the shareholders and the managers.

The agency theory underlined not only the conflicts of interest that may arise between the shareholders and the managers, but also the conflicts between the shareholders themselves (Jensen and Meckling, 1976), and more specifically between the supervising and the minority shareholders.

The controlling shareholder might be haunted by the inclination to take over a part of the wealth generated by the 
company, and at the expense of the interests of the minority shareholders. As a consequence, such conflicts could affect the quality of the accounting information (Fama and Jensen, 1983). In this study, the focus is on the concentration as a feature of the ownership structure.

According to Jensen and Meckling (1976), ownership concentration is an important control mechanism of the agency problems. On the other hand, Shleifer and Vishney (1986), Agrawal and Mandelker (1990), as well as Omri (2002), pointed out the existence of a positive relationship between ownership concentration and the supervising efficiency. On their part, Dechow et al (1996) argued that ownership concentration improves the credibility of the financial statements by promoting a strict control over the earnings management.

Morck et al. (1988) underlined, in particular, the importance of the majority shareholders' interests within the firm, and the active role that the latter play in the officers' supervision and discipline. They stressed that these shareholders, who are the majority, are considered to be more active than the minority actors regarding corporate governance.

Nevertheless, a concentrated ownership structure may encourage the majority shareholders to expropriate minority ones. Actually, for Claessens et al. (2000), a concentrated ownership structure helps the large shareholders remember the accounting information and use it for their own accounts by, for example, undervaluing, the profits so as to reduce the income paid to the minority shareholders.

Moreover, Gorton and Shmid (2000), as well as Dyck and Zingales (2004) found that concentrated ownership structure raises some agency problems between the majority and minority shareholders. Moreover, several studies were conducted on the relationship between capital concentration and the accounting information quality.

On this basis, working on a sample of 1618

American firms for the1988/1990 period, Warfield, Wild and Wild (1995) showed that the informational content of the accounting profits increases in connection with the capital rate held by the directors, officers and the main owners.

For his part, Alves (2012) in a study in the Portuguese context confirms the existence of a negative relationship between capital concentration and the earnings management measured by the discretionary accruals. Moreover, in the French context, Nadia (2015) underlined the negative association between ownership structure and earnings management.

However, Limpaphayom and Manmettakul (2004) put into perspective the positive impact of capital concentration on the earnings management, and more precisely on the level of the discretionary accruals. Furthermore, Asku et al. (2013) showed that ownership concentration is an obstacle for the quality of the accounting results since it causes the discretionary accruals to increase.

Eventually, in a study carried out in the French context, Ben Slama et al (2007) found no significant relationship between capital concentration and the informational content of the accounting profits. It can therefore be noted that the previously mentioned studies were conducted on the developed or the developing countries. They actually could help establish a positive or negative relationship between ownership concentration and the financial information quality.

Taking into account the specificities of the Tunisian context, it would therefore be interesting to test this relationship, which gives us the following hypothesis:

H4: Ownership concentration is positively correlated with the earnings management.

\section{The Impacts of the Audit Quality}

External audit is an important function for the investors because it is a controlling mechanism of the manager. Actually, the statutory auditor should reveal any mismanagement or fraud to the prosecutor. For this purpose, business leaders ensure that the accounts are true and fair and represent the real image of the company. 
The audit quality is defined by Deangelo (1981) as "the probability that the external auditor detects an anomaly in the financial statements (his competence) and reveals it to the market (his independence)".

According to Wallace (1980), investors recommend to audit and verify the financial statements since they underline their investment decisions. This fact brings us to say that external audit is a process that adds value to financial information and helps its distinction. According to Jensen and Meckling (1976), external audit is a supervising mechanism which helps meet the need for obligation or justification. Such an approach of the external audit of Jensen and Meckling (1976) has also been validated by Watts and Zimmerman (1983) - then by Grand (1996), in what they equate it with a way to reduce the agency costs.

\section{The Size of the Audit Firm}

Although the audit quality is primarily related to the Auditor's independence and competence, some researchers resort to the size of the audit firm to evaluate it. DeAngelo (1981) considers that large auditing companies, in this case the "Big4", are more likely to offer a better audit quality because they have better infrastructure, larger and better trained teams, etc.

More particularly, Deangelo (1981) identified three reasons to justify the relationship between the belonging of the Auditors to the group 'big' and the audit quality itself. Firstly, the 'big' auditors have more financial resources than others, the thing which increases the probability of legal action against them in the event of fraudulent financial statements. This would encourage the audit firm to develop quality audit reports. Then, the risk of losing reputation is much higher for these firms than for others, especially if a fraud was revealed.

Finally, due to their size, the 'big' auditors can more easily absorb the loss of a mandate in case of refusal to certify the accounts. Several studies take into account the size of the audit firm as a gage measurement of the quality of the performed audit work.

The presumptions put forward by Deangelo (1981) go along the same line of work of Becker et al (1998) who, in order to study the impact of the audit quality on the earnings management, used the size of the audit firm as a measure of the audit quality. Furthermore, Jeong and Rho (2004), and Pouraghajan et al (2013), found no significant relationship between the size of the audit firm and the earnings management (approximated by the discretionary accruals).

Recently, Piyawiboon (2015) has advocated a minimization of level of the discretionary accruals affected by the size of the audit firm in question.

\section{The Auditor's Specialization}

The literature identified another measure of the audit quality, namely the auditor's specialization. Actually, it is widely accepted that auditors specialized in the industry provide a good quality service because they have specific audit knowledge that prepares them better than others to discover any offence or fraud reported in the accounts, which reaffirms audit quality. Furthermore, Johnson et al. (1991) pointed out that the auditor's specialization in the industry helps the detection of anomalies in the financial reports, and thereby the audit quality in question. Balsam et al. (2003) also attested that the auditors specialized in the industry are able to offer services of good quality than the other auditors.

\section{The Audit Firm Reputation}

It has been clearly shown that the audit firm reputation, which is perceived by customers, is a factor of the external auditor's success (Wilson and Grimlund, 1990; Brozovsky and Richardson, 1998). This reputation is often acquired with time, in conjunction with the progress of the audit work carried out in the office, via well-qualified auditors. Moreover, Watts and Zimmerman (1983) believe that reputation is an essential incentive for the audit quality, depending on the auditors who must be competent and independent 
to be able to provide the required audit services.

Moreover, Beatty (1989) predicted that the audit firms which invest more in reputation are the most invited to reduce errors, especially at the level of the reports submitted by them. Besides, Anderson and Zghal (1994) assimilated the "big4" effect to that of the reputation encouraging firms to offer service quality. Finally, in the wake of what comes to be stated by the researchers in this field, Krishnan (2003) found that the external auditor reputation enhances the information content of the published result.

After having presented the dimensions of the audit quality, we will focus, in what follows, on the various studies dealing with the relationship between the audit quality and financial reporting. Actually, Becker et al (1998), Francis et al (1999) showed that "big4" firms are well equipped to force the earnings management, compared to the 'non-Big4. These same researchers found that 'non-big4' auditors' clients have higher levels of discretionary accruals.

Furthermore, Teoh and Wong (1993) underlined the existence of a positive relationship between the "big4" and the relevance of the accounting result. For his part, Taylor (2003) considered the importance of the role played by the control carried out by the "big4" in the reliability of the financial statements at the level of Australian companies. He managed to prove that there is no significant difference at the level of the accounting profit quality between companies audited by "big4" and those audited by "non-big4".

As for Hall and Wang (2006), they reported that the quality of the accounting profit is better for companies audited by the "big4", mainly in the countries that provide greater protection for investors.

Furthermore, Zhou and Elder (2003) approved that "big4" auditors more often generate a low level of earnings management, and therefore a better quality result. In the light of what has just been stated, in accordance with the specificities of the Tunisian context, it could be assumed that the audit quality, which is approached by the size of the audit firm, the auditor's specialization, and the reputation of the audit firm, improves the quality of the financial information while minimizing the earnings management, therefore, the following hypothesis can be stated:

H5: The audit quality of the "big4" negatively impacts the earnings management (or the level of the discretionary accruals).

\section{Research Methodology}

In what follows, we will present the research sample, the process of the data collection, the research model, and the different variables it contains.

\section{Sample and Data Collection Procedure}

Our research sample consists of 16 companies listed on the Tunisian Stock Exchange (TSE) examined during the 2001/2009 period. Actually, we preferred to exclude from our sample the financial institutions, such as banks, insurance and leasing companies due to the specificity of their accounting rules. Moreover, we excluded other companies because of the non-availability of the required data.

Furthermore, the accounting data were extracted from the companies' annual reports, balance sheets and income statements, as they are published in the Official Gazette of the Financial Market Board. They had subsequently undergone treatment and analysis via the statistical software-STATA 10.

\section{Operationalization of the Different Variables of the Model}

In what follows, we will present various measures related to the variables of our research model. To operationalize the earnings management, we will make use of a proxy, namely the notion of the discretionary accruals. The accruals, which are, in fact, broken down into a discretionary part and a non-discretionary one, are obtained from the difference between the net profit and operating cash flow (Healy, 1985). In other words, the incomes and charges are carried out 
without any flow, such as appropriations to depreciation. The estimation model deployed would be that of Jones (1991) to which some changes were brought in (in 1995).

This model is as follows:

$$
\begin{aligned}
& A_{C C T_{i t}} / T A_{i t-1}=\alpha_{s}\left(1 / T A_{i t-1}\right)+\beta_{s}\left(P P E_{i t} / T A_{i t-1}\right) \\
& +\delta_{S}\left(\Delta R E V_{i t}-\Delta R E C_{i t} / T A_{i t-1}\right)+\varepsilon_{i t}
\end{aligned}
$$

With:

- ACCT $_{i t}$ : Total accruals of firm i during year $(\mathrm{t})$

- $\mathrm{TA}_{\mathrm{it}-1}$ : Total assets of firm i during year (t-1)

- $\triangle \mathrm{REV}$ it: Revenues in year (t) less revenues in year $(\mathrm{t}-1)$

- $\triangle \mathrm{REC}$ it: Variation of the receivables of firm i during years $(\mathrm{t})$ and $(\mathrm{t}-1)$

- PPE ${ }_{i t}$ : Property plant and equipment

- $\varepsilon_{i t}$ : Error term of firm i during year $(\mathrm{t})$

- $\alpha_{s}, \beta_{s}$ and $\delta_{s}: \quad$ Model coefficients estimated for each year and at the level of each activity sector.

It should be noted that the discretionary accruals are obtained by the difference between the total accruals of each firm and the normal accruals (assumed to be nondiscretionary) identified using the Jones's modified model parameters. Formally, for each i firm, and during year $t$, we get:

$A C C D_{i t} / T A_{i t-1}=A C C T_{0} / T A_{i t-1}-\left[\alpha_{s} / T A_{t-1}+\right.$ $\left.\beta_{s} P P E / T A_{i t-1}+\delta_{s} \Delta R E V_{i t}-\Delta R E C_{i t} / T A_{i t-1}\right]$

With: - ACCD it: Discretionary accruals of firm i during year $t$.

\section{The Research Model}

To analyze the impact of the governance mechanisms on the earnings management, we will propose the following template, including the company's size as a control variable.
Our model is therefore as follows:

$A C C D_{i t}=\alpha_{0}+\alpha_{1} S_{\text {SIZE }}{ }_{i t}+\alpha_{2} D U A L_{i t}+\alpha_{3} I N D P_{i t}$ $+B I G 4_{i t}+\alpha_{5}$ NATACT ${ }_{i t}+\alpha_{6}$ SIZE $1_{i t}$

With:

ACCD: Discretionary accruals: The concept of the discretionary accruals is used to operationalize the result management.

SIZE: The Board of Directors' Size. This variable is measured by the total number of directors who sit on the Board of Directors.

DUAL: The Board of Directors' Duality. This variable helps find out if there is a separation or an accumulation of functions of chief executive officer and Chairman of the Board of Directors. Being binary, it takes value 1 if the CEO is at the same the chairman of the Board, and 0 otherwise.

INDP: Proportion of independent directors in the Board. It is the ratio between the number of independent directors and the total number of directors.

BIG4: This is a measurement indicator of the audit quality. This is a binary variable that takes value 1 if the firm is audited by a "BIG4"; otherwise, it takes value 0.

NATACT: This variable, which is used to assess the degree of capital concentration, is dichotomous. It takes value $1(0)$ when the percentage held by the largest shareholder is more (less) than 50\%.

SIZE1: Size of the target company. This variable is approximated by the normal turnover logarithm.

\section{Interpretation of the Main Results}

In what follows, there is a presentation of the main descriptive statistics and the results obtained on the basis of the test of our research model on STATA 10.

\section{Descriptive statistics}

The following table presents the descriptive statistics obtained at the end of our study. 
Table 1: Descriptive statistics

\begin{tabular}{|l|c|c|c|c|c|}
\hline & Number of observations & Average & Standard deviation & Minimum & Maximum \\
\hline ACCD & 119 & 0.3381 & 3.8594 & -2.2485 & 41.46421 \\
\hline SIZE & 160 & 9.2562 & 1.77777 & 5 & 12 \\
\hline DUAL & 160 & 0.7437 & 0.4379 & 0 & 1 \\
\hline INDP & 160 & 0.0016 & 0.0018 & 0 & 0.006 \\
\hline BIG4 & 160 & 0.1875 & 0.39153 & 0 & 1 \\
\hline ACTNAT & 160 & 0.3062 & 0.46238 & 0 & 1 \\
\hline SIZE1 & 158 & 11.0666 & 1.034792 & 7.32449 & 14.24972 \\
\hline
\end{tabular}

The descriptive statistics revealed a number of business-related characteristics of our sample. It is noted that the Board's size is on average equal to 9.25 members and varies between a minimum of 5 and a maximum of 12 . Compared to the assumptions of Lorch and Lipton (1992) for which the optimal size is at a level of seven to eight members, the average obtained size is relatively high. Nevertheless, it is considered comparable with the one found by Feki and Khoufi (2010) in their research conducted in 2010 on a sample of French companies.

Moreover, it can be noted that the BIG4 variable has an average of 0.18 ; which implies that $18 \%$ of the studied sample companies employ auditors belonging to the "BIG4" and that the DUAL variable has an average of 0.74 , which means that in $74 \%$ of the companies covered in this study, the CEO is also the chairman of the Board of Directors. It can be concluded that few firms are subject to effective control by a separation of functions; which implies a good administration as recommended by the agency theory.

\section{The Research Model Test}

To test the impact of the governance mechanisms on the earnings management, the ordinary least squares method (OLS) will be used.

Table 2: Estimating the model coefficients on the basis of the OLS method

\begin{tabular}{|l|c|c|c|}
\hline & Coefficient & t-student & Probability \\
\hline SIZE & 0.4016 & 1.48 & 0.139 \\
\hline DUAL & 1.197 & 1.07 & 0.283 \\
\hline INDP & 32.690 & 0.11 & 0.914 \\
\hline BIG4 & 0.4074 & 0.32 & 0.746 \\
\hline ACTNAT & $2.900^{*}$ & 2.88 & 0.004 \\
\hline SIZE1 & $-1.164^{* *}$ & -2.50 & 0.013 \\
\hline CONSTANTE & 7.454 & 1.56 & 0.118 \\
\hline
\end{tabular}

Notes: *: significance at $1 \%$; ${ }^{* *}$ : significance at $5 \%$.

The research hypotheses test through the multi-varied regression analysis helps validate some hypotheses and invalidate others.

The Board's size seems to have no effect on the earnings management. This means that the variable-related coefficient is positive at 0.40 , but non-significant $(\mathrm{p}=0.139)$. This result is, however, inconsistent with the theory postulates, which calls into question the role played by the Board of Directors as a monitoring mechanism that 
helps minimize the leader's opportunistic behavior.

Moreover, such results corroborate those obtained in the studies of Mezghani and Ellouz (2011) - in the Tunisian context, and those of Uzum et al (2004) in the American context. These authors actually found no significant relationship between the Board's size and the existence of fraud in the financial reports.

Therefore, one could decide about the fact that the Board's size has no effect on the earnings management of the Tunisian companies. Actually, the presence of a big or small number of members on the Board of Directors is therefore not a governance mechanism.

Moreover, dual function seems to have no effect on the earnings management. The coefficient related to this variable is positive at 1197, but statistically insignificant $(p=0.28)$. This result is in unconformity with those found by Forker (1992) and Dechow et al (1996) and recently by Aysha and Abdullah (2015) who reported the existence of a positive and significant relationship between the dual function of the CEO and the Chairman of the Board of Directors, on the one hand, and the earnings management, on the other hand. However, the results found confirm those of Coulton (2001) and Mahfuja Malik (2015), who found no significant relationship between duality and earnings management.

In Tunisia, the monistic form is the most widespread; which results in the fact that the Chief Executive often holds the post of chairman. However, this duality in itself has no significant effect on the earnings management of the Tunisian companies. This can be explained by, among other things, the fact that the separation of functions is not a governance mechanism.

Moreover, we find that the INDP variable, which has a positive coefficient of 32.69, was not significant $(p=0.91)$. This result seems to be in conformity with those found by Vafeas (2000) who suggests that no significant relationship is checked between the proportion of the outside directors on the board and the information profit content. However, this very same result is in discordance with the ones found by Peasnell et al. (1998, 2000), and Klein (2002). In fact, these authors identified a negative association between the Board's independence and earnings management. In Tunisia, it seems that the directors' independence is not a discipline mechanism for the manager.

Moreover, it can also be noticed that the audit quality has no significant effect on the earnings management, since the coefficient related to this variable, which is positive in the range of 0.40 , is not statistically significant $(p=0.74)$. Similarly, the work of Jeong and Rho (2004), and those of Abbasali Pouraghajan et al (2013) and Kamran and Attaulah (2014), have not been able to come to a significant relationship between audit quality measured by the size of the audit firm and the result management approached by the discretionary accruals approximate.

On the other hand, the studies of Becker et al (1998) and Francis et al (1999) go in the same line with the achieved results since they show that the audit quality is associated with a low level of earnings management. In Tunisia, the size of the audit firm is not a manager's governance mechanism. Moreover, Tunisian companies do not hire audit firms belonging to the "BIG4" to control their executives.

It is also apparent that the ownership structure impact on the earnings management is positive and significant $(\mathrm{p}=$ 0.004), with a coefficient of 2.9; which implies an increase in ownership structure raises the accruals. Therefore, it can be deduced that according to our expectations, ownership structure development leads to an increase of the level of the discretionary accruals. This hypothesis is in line with the contributions of Fan and Wong (2002) that proved, on the basis of a sample of 977 companies from seven Southeast Asian economies, that the informational content of the accounting result declines. Similarly, Limpaphayom and Manmettakul (2004) and Ming and Chiow (2015), being opposed to Iraya et al (2015) supported the positive impact of capital concentration on the earnings management, and more 
particularly on the level of the discretionary accruals. In Tunisia, it could be predicted that if ownership structure increases, the leader benefits most often from the situation and therefore manipulates the accounting profit.

Our model also shows that company's size has a negative effect on the discretionary accruals; since the coefficient of this variable is negative and significant ( $t$ statistics $=-2.50)$. This result seems to contradict most of the previous results achieved in this regard, such as those of Makrani and Maryam (2014). Moreover, this result is in line with those approved by Davidson et al (2005) and Klein (2002), which showed that the company's size negatively impacts the earnings management. In Tunisia, the company's size is a factor that appears to decrease the earnings management. This could be explained by the fact that it is in large companies, where the turnover is quite important, that the manager may manipulate the accounting result.

\section{Conclusion}

Through this contribution level, it is possible to test the relationship between the governance mechanisms and the earnings management on a representative sample of 16 Tunisian companies during the $2001 / 2010$ period. For this purpose, we resorted to the ordinary least squares method and more specifically to the statistical data-processing software STATA 10 .

Our results mainly showed that the earnings management is positively related to the ownership structure and the company's size. However, no association was confirmed between the Board of Directors, the audit quality, on the one hand, and the level of discretionary accruals, on the other hand.

Furthermore, our research has some limitations. First, the size of the sample composed of only 16 companies listed on the Tunis Stock Exchange is considered limited. Hence, the use of the concept of the discretionary accruals, as a measure of earnings management while eradicating all other variables such as spending on research and development, would also be quite reductive in relation to the possibility of generalizing the results.

Finally, our representative model of earnings management based on governance mechanisms could be extended to other cultural variables or related to the Tunisian context. In terms of future research directions, we could be more open to other research paths, such as those related to the impact of the governance mechanisms on the earnings management. A comparative study between countries of the common law and customary law of a country, for example, could serve this purpose.

\section{References}

1. Adam, S. (1776). Wealth of the Nation. Book-5, Chapter1, 255.

2. Afua, A. B. A., Francis A. O., and Bedi, I. (2014). Earnings management and corporate governance: the Ghanaian experience, Int. J. Management Practice, 7, (4), 309-323.

3. Agrawal, A., et Mandelker, G. (1990). Large shareholders and the monitoring of managers: the case of takeover charter amendment. Journal of Financial and Quantitative Analysis, 25(2), 143-161.

4. Anderson, T., and Zéghal, D. (1994). The pricing of audit services further evidence from the Canadian market. Accounting and business research, 24, (95), 195-207.

5. Aksu, M. H., Muradoglu, Y. G., et Tansel C. A. (2013). Ownership Concentration, IFRS Adoption and Earnings Quality: Evidence from an Emerging Market (August 30, 2013). Available at SSRN:http://ssrn.com/abstract=2382930.

6. Alchian, A. A., and Demsetz, H. (1972). Production, Information Costs and Economic Organization. American Economic Review, 777-795.

7. Aliyu, S. K ., and Ishaq, A. S. (2015). Board Characteristics, Independent Audit Committee and Financial Reporting Quality of Oil Marketing Firms: Evidence from 
Nigeria. Journal of Finance, Accounting and Management, 6(2), 34-50.

8. Alves, S. (2012). Ownership Structure and Earnings Management: Evidence from Portugal. Australasian Accounting, Business and Finance Journal, 6(1), 57-74.

9. Alves, S. (2014). The Effect of Board Independence on the Earnings Quality, Evidence from Portuguese Listed Companies. Australasian Accounting, Business and Finance Journal, 8(3), 23-44.

10. Awaisu, A. S. and Rabiu, S. J.(2015).The effect Of Board The Size And Audit Committee The size On Earnings Management In Nigerian Consumer Industries Copmanies.International Journal Of Innovative research And development, 4(3), 84-90.

11. Aysha, S. L. and Fahad, A. (2015). The Effectiveness of Corporate Governance in Constraining Earnings Management in Pakistan.The Lahore Journal of Economics, 20 (1), 135-155.

12. Balsam, S., Krishnan, J., and Yang, J. S. (2003). Auditor Industry Specialization and Earnings Quality. Auditing: A Journal of Practice et Theory, 22(2), 71-97.

13. Beatty, R. P. (1989). Auditor Reputation and the Pricing of Initial Public Offerings . The Accounting Review, 64, 693709.

14. Becker, C. L., DeFond, M. L., Jiambalvo, J., and Subramanyam, K. R. (1998). The effect of audit quality on earnings management. Contemporary Accounting Research, 15 (1), 1-24.

15. Benayed, K. H. (2009). L'impact des mécanismes interne de gouvernement de l'entreprise sur la qualité de l'information comptable. La place de la dimension européenne dans la Comptabilité le contrôle et l'audit, May 2009, Strasbourg, France. pp.CD- ROM. <halshs-00460918>.

16. Benslama, F., Matoussi, H., and Pigé, B. (2007). Gouvernance d'entreprise et pouvoir informationnel des bénéfices comptables en France et aux Etats-Unis. 28ème Congrès de l'Association
Francophone de Comptabilité, Poitiers, 116.

17. DeAngelo, L. E. (1981). Auditor size and audit quality. Journal of Accounting Economics, 3(2), 183-199.

18. Brozovsky, J. A., and Richardson, F. M. (1998). The Effect of Information Availability on the Benefits Accured from Enhancing Audit-Firm Reputation. Accounting, Organizations and Society, 23, 767-779.

19. Chadanat, P. (2015). Audit Quality, Effectiveness of Board Audit Committee and Earning Quality. Rev. Integr. Bus. Econ. Res, 4(2), 366-377.

20. Charreaux, G. (1997). Le gouvernement des entreprises. Economica, 540. Principes de l'OCDE. (2004).

21. Chen, Z., Cheung, Y. L., Stouraitis, A., and Wong, A. W. S. (2005b). Ownership concentration, firm performance, and dividend policy in Hong Kong. Pacific-Basin Finance Journal, 13(4), 431- 449.

22. Chtourou, M. S., Bédard, J., and Courteau, L. (2001). Corporate governance and earnings management. Working paper, Laval University, 1-41.

23. Claessens, S., Djankov, S., Fan, J., and Lang, L. (2000). Expropriation of Minority Shareholders in East Asia. CEI Working Paper Series, 2000-4.

24. Coulton, J., James, C., and Taylor, S. L. (2001). The effet of compensation design and corporate governance on the transparency of CEO compensation disclosures. Finance-controle-stratégie, 1(2), 57-88.

25. Cyrus, I., Mirie, M., and Gilbert, W. M. (2015).The Effect Of Corporate Governance Practices On Earnings Management of Companies Listed At The Nairobi Securities Exchange. European Scientific Journal, 11(1), Issn 1857-7881.

26. Davidson, R., Goodwin-Stewart, J., and Kent, P. (2005). Internal governance structures and earnings management. Accounting and Finance, 45(2), 241-267. 
27. Dechow, P., Sloan, R., and Sweeney, A. P. (1996). Causes and consequences of earnings manipulation. Contemporary Accounting Research, 13, 1-36.

28. Dyck, A., and Zingales, L. (2004). Private Benefits of Control: An International Comparison. Journal of Finance, 59(2), 537-600.

29. Faghani, M., and Amoei, M. (2014). Investigating the Relationship of Corporate Governance Mechanisms, Company Size, and Earning Management of Accepted Companies in Tehran Stock Exchange Research. Journal of Recent Sciences, 3(7), 90-97.

30. Fama, E., Jensen, M. C. (1983a). Separation of Ownership and control. Journal of Law and Economics, 26( 2), 301-325.

31. Fan, J. P. H., and Wong, T. J. (2002). Corporate ownership structure and the informativeness of accounting earnings in East Asia. Journal of Accounting and Economics, 33, 401- 425.

32. Feki, A., and Khoufi, W. (2008). L'effet des caractéristiques du conseil d'administration et de la qualité de l'information financière sur le coût de la dette (Cas des entreprises industrielles française). La comptabilité, le contrôle et l'audit entre changement et stabilité, May 2008, France.

33. Francis, J. R., Hall, C., and Wang, D. (2006). The Joint Effect of Investor Protection and Big 4 Audits on Earnings Quality around the World. documents de travail, SSRN.

34. Francis, J. R., Maydew, E. L., and Sparks, H. C. (1999). The role of big 6 auditors in the credible reporting of accruals . Auditing: a Journal of Practice \& Theory, 18, (2), 17-34.

35. Forker, J. J. (1992). Corporate governance and disclosure quality. Acounting and Busniess Research, 22.

36. Grand, B. (1996). Approches théoriques de l'audit. Working Paper $n^{\circ}$ 469, Centre d'Études et de Recherches sur les Organisations et la Gestion (CEROG), IAE Aix-en-Provence, Université AixMarseille III.

37. Gorton, G., and Schmid, F. A. (2000). Class struggle insider the firm. A study of German code termination, Working Paper, 2000, 7945.

38. Healy P., (1985). The effect of bonus schemes on accounting decisions, Journal of accounting and economics, 7, p. 85-107.

39. Haniffa, R., and Cooke, T. (2000). Culture, corporate governance and disclosure in Malaysian corporations. Document de travail.

40. Hermalin, B. E., and Weisback, M. S. (2003). Board of Directors as an Endogenously Determined Institution: A Survey of the Economic Literature. Center for Responsible Business. Working Paper Series. Paper 3.

41. Jaggi, B., Leung, S., and Gul, F. (2009). Family control, board independence and earnings management: Evidence based on Hong Kong firms. Journal of Accounting and Public Policy, 28(4), 281-300.

42. Jensen, M. C. (1993). The modern industrial revolution, exit and the failure of internal control systems. Journal of Finance, 48(3), 831-880.

43. Jensen, M. C., and Meckling, W. H. (1976). Theory of the Firm: Managerial Behavior, Agency Costs and Ownership Structure. Journal of Financial Economics (October 1976) ,305-360.

44. Jeong, S. W., and Rho, J. (2004). Big Six auditors and audit quality: the Korean evidence.The International Journal of Accounting, 39(2), 175-196.

45. Jesus, S. G., and Emma, G. M. (2014). Does Corporate Governance Influence Earnings Management In Latin American Markets? journal of Business Ethics, 121(3), 419-440.

46. Johnson , P. E., Jamal, K., and Berryman, R. G. (1991). Effects of Framing on Auditors Decisions .Organizational 
Behavior and Human Decision Processes, 50, 75-105.

47. Kamran., et Attaullah, S. (2014). The Impact of Corporate Governance and Ownership Structure on Earnings Management Practices: Evidence from Listed Companies in Pakistan. The Lahore Journal of Economics 19 (2), 27-70

48. Klein, A. (2002). Audit Committee, Board of Director Characteristics, and Earnings Management. Journal of Accounting and Economics, 33 (3), 375400.

49. Klein, B. R., and Leffler, k. (1981). The role of market forces in assuring contractual performance. Journal of political economy, 89, 615-641.

50. Krishnan, G. P. (2003). Audit quality and the pricing of discretionary accruals. Auditing : a Journal of practice and theory, 10(1), 35-52.

51. Limpaphayom, P., Manmettakul, S. (2004). Managerial ownership and informativeness of earnings: evidence from Thailand after the Asian Financial Crisis. American Accounting Association, Annual Meeting, Orlando Florida (August 8-11).

52. Lipton, M. and Lorsch, J. W. 1992. A Modest Proposal for Improved Corporate Governance. Business Lawyer, 48, (1), 5977.

53. Lynda, I., and Khemakhem, H. (2015). The Impact of Audit Committee Characteristics on Earnings Management: A Canadian Case Study. Case Studies in Business and Management, ISSN 23333324 2015, 2, (1).

54. Mahfuja, M. (2015). Corporate Governance and Real Earnings Management: The Role of The Board and Institutional Investors.Journal of Knowledge Globalization, 8(1), 35-85.

55. Mansourinia, E. (2013). The Effect of Audit Quality on Earnings Management, Evidence from Iran . International Journal of Basic Sciences \& Applied Research, 2 (4), 399-404.
56. Masmoudi, A. W., and Boujelben, Y. (2014). The relationship between ownership structure and earnings quality in the French context. International Journal of Accounting and Economics Studies, 2 (2), 80-87.

57. Matoussi, H., and Mahfoudh, I. (2010). Composition du conseil d'administration et gestion opportuniste des résultats. Comptabilité, contrôle, audit et institution, May 2006, Tunisie.

58. Mehmet, A., Suleyman, Ic et Mustafa, S. (2014). The Effects of Corporate Ownership Structure and Board Size on Earnings Management: Evidence from Turkey. International Journal of Business and Management, 9, (12), 123-132

59. Mezghani, A. and Ellouze, A. (2007). Gouvernement d'entreprises et qualité de l'information financière. Comptabilité et environnement, May 2007, ' France. pp.CDRom.

60. Ming, F.H., and Shiow, Y.W. (2015). The Influence of Corporate Governance In Chinese Copanies On Discretionary Accrauls And Real Earnings Management.Asian Economic And Financial Review, 5(3), 391-406.

61. Monks, R., Minow, N. (1995). Corporate Governance .Blackwell, Cambridge, MA.

62. Morck, R., Shleifer, A., and Vishny, W. (1988). Management ownership et market valuation. Journal of Financial Economics, $20,293-315$.

63. Nadia, L. (2015). Corporate Disclosure, Ownership Structure And Earnings Management: The Case of French-Listed Firms. The Journal of Applied Business Research - July/August 2015, 31, (4), 1493-1504.

64. Omri, M. A. (2002). Rôle des investisseurs institutionnels et performances des entreprises tunisiennes ».http://unpan1.un.org/intrad oc/groups/public/documents/CAFRAD/U NPAN005533.pdf. 
65. Omri, A., and Mhiri, B. (2003). Performance des entreprises tunisiennes. Working paper.

66. Peasnell, K., Pope, P., and Young, S. (1998). Outside directors, board effectiveness and earnings management. Working Paper accounting, reaserch network.

67. Peasnell, K., Pope, P., and Young, S. (2000). Detecting earnings management using cross-sectional abnormal accruals models. Accounting and Business Research, 30(4), 313-326.

68. Pfeffer, J. (1972). Size and composition of corporate boards of directors: the organization and its environment. Administrative Science Quarterly,17, 218228.

69. Pouraghajan, A., Yadollahzadeh, N. A. T., Emamgholipour, M., and Mansourinia, E. (2013). The Effect of Audit Quality on Earnings Management, Evidence from Iran. International Journal of Basic Sciences \& Applied Research, 2 (4), 399-404.

70. Sarah, G. (2015). The Effect Of Board And Audit Committee Characteristics On Real Earnings Management: Do Boards And Audit Committee Play A Role In Its Promotion Or Constraint? Academy of Accounting and Financial Studies Journal, 19(1), 64-87.

71. Schipper, K. (1989). Commentary on earnings management. Accounting Horizons, 3(4), 91-102.

72. Shleifer, A., and Vishny, R. W. (1986). Large shareholders and corporate control. Journal of Political Economy, 94(3), 461488.

73. Shleifer, A., and Vishny, R.W. (1989). Management Entrenchment: the Case of Manager Specific Investments. Journal of Financial Economics, 123-139.

74. Stepniewski, J., and Souid, S. (2008). Indépendance du conseil d'administration et gestion du résultat. La comptabilité, le contrôle et l'audit entre changement et stabilité, May 2008, France.
75. Taylor, S. (2003). The impact of audit quality on earnings conservatism: Australian evidence », document de travail.

76. Teoh, S. H., and Wong, T. J. ( 1993). Perceived auditor quality and the earnings response Coefficient . The Accounting Review, 68, Avril, 346.366.

77. Uwalomwa, U ., Daramola S. P., and Anjolaoluwa, O. (2014). The effects of corporate governance mechanisms on earnings management of listed firms in Nigeria. Accounting and Management Information Systems Vol. 13, No. 1, pp. 159-174, 2014.

78. Uzn, H., Szewczyk, S. H., et Varma, R. (2004). Board composition and corporate fraud.

79. Vafeas, N. (2000). Board structure and the informativeness of earnings. Journal of Accounting and Public Policy, 19, Summer, 139-160.

80. Watts, R. L., and Zimmerman, J. (1978). Towards a positive theory of the determination of accounting standards. The Accounting Review, 53(1), 112-134.

81. Watts, R.L., and Zimmerman, J. L. (1983). Agency problems, auditing, and the theory of the firm: some evidence. Journal of Law \& Economics, 26,613-633.

82. Wallace, W. (1980). The Economic Role of the Audit in Free and Regulated Markets. Touche Ross Teaching Tool.

83. Warfield, T., Wild, J. J., and Wild, K. L. (1995). Managerial ownership, accounting choices, and informativeness of earnings . Journal of Accounting and Economics, 20, 61-91.

84. Wasukarn, N. (2015). Impact of Board Effectiveness and Shareholders Structure on Earnings Management in Thailand. Rev. Integr. Bus. Econ. Res, 4(2), 342-354

85. Williamson, O. E. (1985). The Economic Institutions of Capitalism. The Free Press, 1985.

86. Wilson, T., Grimlund, R. (1990). An Examination of the Importance of an 
Auditor's Reputation, Auditing . A Journal of Practice and Theory, 9, 43-59.

87. Yermack, D. (1996). Higher market valuation of companies with a small board of directors. Journal of Financial Economics, 40, 185-211.

88. Yung-Chuan, L. (2013). Can Independent Directors Improve the Quality of Earnings? Evidence from Taiwan. Advances in Management \& Applied Economics, 3(3), 45-66.

89. Zhou, J., and Elder, R. (2003). Audit firm size, industry specialization and earnings management by initial public offering firms. Working paper, Syracuse University, Syracuse, NY and SUNYBinghamton, Binghamton, NY. 